\title{
Experience, Engagement and Vision
}

I first met Heidi Boutros when she enrolled in my introductory class on Buddhism in the spring semester of 2001 at the University of Texas at Austin. She always sat in the front row, and was silent in class, but her silence had an intensity to it that indicated to me that it was caused by something other than boredom or by feeling overwhelmed. As it turned out, in Heidi's case, the silence was that of intense interest and concentration; everything that I said in lecture was being carefully weighed and categorized. We had our first real conversation after I distributed a list of possible paper topics to my class of seventy. On the list was the suggestion that students might write a paper on a topic of contemporary relevance in which they were actively interested and engaged - human rights, reproductive rights, or capital punishment, for example - and research the issue in a specifically Buddhist cultural or ethical context. Heidi approached me to ask if she could write a paper on human rights in Chinese-controlled Tibet, and I gave her my approval along with a list of sources, not knowing at the time that as a college sophomore, she was already an experienced human rights investigator. She had spent the summer after her freshman year working in Russia with the Moscow Center for Prison Reform. My grader for the course singled out her paper for its maturity and overall excellence, and brought it to my attention. Heidi had turned in a paper that was not just a report on the many disputed "facts" of human rights abuses in Tibet, but was instead an analytical piece on policy and implementation, written in a language other than that of the sadly quotidian human rights discourse of "witnessing" and "testimony." Heidi's paper moved us on to the next step: analysis and suggestions for change.

After her two-week stint in Chennai in March 2002 with the International Justice Mission (IJM), I heard from Heidi again. She was looking for funds to support a second trip to Chennai. The director of the IJM-Chennai office had offered her a position as a full-time volunteer for the summer. I was personally delighted by this, because I had been conducting research in the city since 1989, and I always feel at my most useful as an advisor to students when they are on their way to Chennai. We decided that Heidi would apply for an Undergraduate Research Scholarship, which required Heidi to sign on 
with me to supervise her study. We agreed that Heidi would write up a substantial report on her experiences as an IJM volunteer, and that I would assign her a grade based on the report. At that time, neither of us had an inkling about where this "paper" was going to go or where it would take us. I knew that Heidi would be documenting her experiences as a member of the IJM team, and that she would be helping conduct bonded slavery interventions in the city. I knew that it would be hot, dirty work, and that she would be a firsthand witness to unimaginable human misery. Heidi was awarded the scholarship. Off she went, and this led me to reflect on what I "knew" about bonded labor in India, which turned out to be next to nothing.

As a specialist in classical Indian literature, I spend much of my time in Chennai in libraries, looking at crumbling palm-leaf manuscripts, with my nose stuck in dictionaries or in deep conversation with local scholars over issues of textual interpretation or classical Tamil syntax. But as a long-time, semi-permanent resident of the city, I was also aware of its problems, but not of the full complexities of its problems. I certainly knew that bonded labor existed. One sees it in action every day. I had heard rumors, for instance, that many of the city's beggars were "owned" by "bosses" — the Tamil word for "boss" is mudalali, which tellingly means "proprietor" or even "capitalist" in other, somewhat more savory contexts. I was in a rickshaw one hot morning, stalled in a traffic jam in the center of town, when a beggar, dressed in rags and clutching a squalling infant to her chest, assailed me for cash: Paisa, Ma, paisa, Ma, baby bungry, Ma, paisa, Ma. Over the protestations of the rickshaw driver, I gave her a few coins, and since we were stalled in traffic, I then asked her a cheeky question: Unka mudalali enke, Ma? ("Where's your bossman, Mother?") She furtively smiled at me, cast her eyes down, and very subtly, and very much to my surprise and to that of the driver, nodded in the direction of the street corner at the next intersection. The traffic unjammed itself somehow, and away we went, but that little exchange transformed my view of beggars for the rest of my life: many of them are working, not begging, and not begging because of character flaws or laziness, but because they are owned, and are paying off insurmountable debt. I later discovered that many of the women I saw at construction sites throughout the city - winnowing sand for cement through screens, chipping stone into gravel; carrying heavy loads of bricks on pieces of twisted coir on their heads - were, in fact, bonded laborers. Slaves. And, in many instances, these women were working off hereditary debt that had been incurred by someone belonging to a previous generation in their families. I knew about it and could put human faces on the problem, 
but I was only interacting with this horrible phenomenon at its most visible surfaces. It was not until Heidi returned from her summer in Chennai and turned in her report that I could even begin to understand the complexities and the interpersonal, intercaste dynamics of the situation, or why bonded labor is so common and so seemingly entrenched in Indian society.

Many students have come to me in my twelve years of teaching with a burning desire to go to India, and for just as many reasons: some are so-called heritage students, and want to go to India so they can somehow make better sense of themselves and their family histories. Others go to hone their language skills in immersion programs, or to learn an instrument or how to dance in a particular Indian regional style. Like Heidi, many go to do volunteer work. These are all valid and admirable reasons. But most students who want to go to India know so little about it, and have exotic images floating in their minds, put there by nostalgic parents or by the media: They are hooked by the Taj Mahal, by the silks and the jasmine, or by notions of the perfect extended family and the romance of the ancestral home. Heidi, however, was lured by harsh realities and her own desire for positive change, and not by an exotic dream.

Heidi's award-winning paper stunned me when I first read it. It demonstrates a very different vision of the world. When Heidi left for Chennai, I had originally envisioned that she would turn in a more "ethnographic" sort of account, listing abuses and describing her encounters with mudalalis and laborers alike. But Heidi's efforts moved far beyond hand-wringing, witnessing, and documenting to doing; from exposing abuses to actual legal intervention. In hindsight, her initial two-week trip to Chennai gave her a clear view of the issues, and this was a valuable experience for her. It allowed the "shock" of the situation to wear off, and it allowed Heidi to move in her own mind from useless pity to active strategy. As a Plan II and Government double major, her study-abroad experience enabled Heidi to learn not just about policy, but to take an active role in the writing and actual implementation of it. Heidi's experience with the IJM in Chennai changed her life, but it also changed the lives of bonded laborers by moving them out of hopeless debt and servitude and into a brighter new world of training and economic opportunity. As I expected, Heidi did indeed document her intervention experiences. But what surprised me was her keen ability to identify systemic weaknesses in NGOs and other aid organizations, and to make positive suggestions for change that allow interventions to occur with greater efficiency, and to bring deliverance to those who need it the most. 
When we send our students to the field, it is a risky business. We burden ourselves with worry and doubt. But when fresh minds are confronted with hopeless situations, great things can happen, especially when that mind knows how to target institutional weakness, analyze, optimize, and develop new strategies for implementation. Heidi's work also teaches us a new sort of human rights advocacy. She has also taught me that empathy for the suffering must move from emotion to reason before any results are possible, and that compassion is ultimately much more a thing of the mind than it is of the heart.

\section{Martha An $\mathrm{n}$ eI by}

Associate Professor of South Asian Studies

The University of Texas at Austin 